\title{
Development of Creative Tourism Zone 'Puncak 2' to Increase Economic Competitivenes of Bogor District
}

\author{
Besar Agung Martono \\ International Program Coordinator \\ STIE IPWIJA \\ Jakarta, Indonesia \\ agungmartono@yahoo.com
}

\author{
Titing Widyastuti \\ Magister Management Program Director \\ STIE IPWIJA \\ Kabupaten Bogor, Indonesia \\ widyamartono@yahoo.com
}

\begin{abstract}
The purpose of this paper is to present a proposed development concept of "Creative Tourism Zone" 'Puncak 2' region in Bogor District. This paper also serves to develop the concept of a Creative Tourism Zone with stakeholders including the government, academia and entrepreneurs. The proposal is based on the concept of Creative Economy theoretical framework UNDP (2008) which is used to assess the factors that create a Creative Tourism Zone for framing the discussion about the further development of the Creative Tourism Zone. 'Puncak 2' region Bogor District has the opportunity and potential to become a Creative Tourism Zone, especially in the context of further increasing tourism Bogor District, tourists both domestic and foreign tourists. However, efforts are needed especially by the creative industries in this zone to form a forum, management and networking to develop this Creative Tourism Zone. Government participation should be increased, by creating conditions that support creativity, for example, with infrastructure development along the lines 'Puncak 2' region. An important finding is that creative economy development zone 'Puncak 2' region could increase the competitiveness of the regional economy through the Bogor District creative industries.
\end{abstract}

Keywords- Puncak 2, Creative Tourism Zone, Creative Economic, Creative Industry

\section{INTRODUCTION}

Cipanas Puncak-plateau 900-1600 meters above sea level and is the closest plateau within easy reach of Jabodetabek. In the era of 1980-1990's were a golden age of natural tourism in Puncak. The location is easily reached less than 1 hour from Jakarta makes Puncak always be the first choice for a weekend getaway or office events such as meetings, outings, and others. The emergence of inns or hotels, restaurants and cafe over time make-Cipanas Puncak increasingly dense and interesting to visit (Syafrudin, 2016).

At the end of the 1990s, the Puncak city experienced major floods. Not the first, but at that time was under the spotlight on the impact of unplanned development in the area is a true highlight of the catchment area, but it was almost fully covered by buildings villa both licensed and illegal. As a result, the Bogor regency administration began displacing some unlicensed buildings and try to restore the function of most of the Puncak area back to normal. It was not easy.
Not to eradicate the crippling villa wild-Cipanas Puncak, but the lack of planning and supervision of the use of space in Puncak Puncak tourism that kills slowly. Huge traffic jam to make the visitors divert tourist visits to other places, especially after the completion of the motorway Cipularang Jakarta Bandung cut travel time to just 2.5 hours. The absence of viable alternative path to reach or leave Cipanas Puncak make Cipanas Puncak tourism dimmed.

And now is the time of a very short open opportunity. What does it mean? Puncak Line 2. Development through the Puncak 2 is the solution that will restore the glory of Cipanas Puncak-rocketed even exceed the golden age in the era of 1980-1990's. Puncak 2 line will be the main line to go to the top and Cipanas because the road width of $30 \mathrm{~m}$ will pamper guests to arrive and return without experiencing congestion as well as in the path of Puncak 1 (Syafrudin, 2016).

Not only that, the construction of Puncak 2 Line also highlight open access that has not been there, the CikarangCipanas. Currently Cikarang and surrounding areas are the areas most 'hot' development. The largest industrial estates in Indonesia continues to clean up to be a prime industrial area in Southeast Asia. Currently, 10,000 expat (foreign employees) work in 2000 and continues to grow more multinational companies. Imagine, when during the Cikarang employees or residents have to travel 1-2 hours to vacation in Jakarta. Later, they simply drive for 45 minutes to arrive at the cool of their choice in Cipanas.

However, development of Puncak 2 should be well-planned to anticipate future global trends called "Creative Tourism Destination Zone" to increase economic competeitiveness of Bogor District. There are several factors and preconditions in order Puncak 2 become creative tourism destination.

The purpose of this paper is to present a proposed development concept of "Creative Tourism Zone" 'Puncak 2' region in Bogor District.

\section{LITERATURE REVIEW}

This paper replicates Goede and Louisa (2012) studied creative economy in Curacao. The term "creative economy" was introduced in Howkins (2001), in Creative Economy, where he describes the relationship between creativity and 
economics. Howkins states that creativity is not new and neither is economics, but the nature and the extent of the relationship between creativity and economics and how they merge to create extraordinary value and wealth are revealing.

As part of creative economy, the creative tourism is considered a new generation of tourism by involving the tourists themselves and the locals in the creation of the tourist products (co-creation) (Porter, 1999)

The Creative Tourism concept appeared in the 2000's, and defined as a: "Tourism which offers visitors the opportunity to develop their creative potential through active participation in courses and learning experiences, which are characteristic of the holiday destination where they are taken." (Raymond and Richards, 2000).

The growing demand for Creative Tourism arouses the interest of the destination managers and local governments, seduced by the opportunity to attract a high value tourism by simply fostering their intangible heritage (workshops) and optimizing the use of existing infrastructures (venues rental).

Among the many virtues of the creative tourism, we can mention the following ones:

- Diversification of the tourist offers without any investment, just by optimizing existing tangible and intangible heritage.

- Positive effects upon the profitability of the cultural infrastructures thanks to this new demand.

- Quality tourism endowed with a high added value and purchasing power.

- Authenticity and sustainability as it uses the creativity as mean resource.

- Positive effect on the self-confidence of the local people thanks to this new interest for their culture and tradition.

- Its deseasonalizing character allows a better distribution of the tourist activity along the year.

- The geographical outsourcing. The minor interest of creative tourists in traditional "tourist attractions" contributes to a better spatial distribution within the destination.

- Intangible heritage recovery. "Creative tourism is a projection of a new tourism in which natural, cultural and personal ressources are not manipulated and exploited but valued and enriched“. (Jelincic and Zuvela, 2012).

Howkins includes a great range of activities as the creative economy, covering 15 creative industries from the arts to science and technology. There are two kinds of creativity: the kind that relates to people's fulfillment as individuals and the kind that generates a product. The former is a universal characteristic of humanity and is found in all societies and cultures. The latter is stronger in industrial societies, which put a higher value on novelty, on scientific and technological innovation and on intellectual property rights (Creative Economy Report, 2008).
At the root of the creative economy are the creative industries. Creative industries can be described as the cycles of creation, production and distribution of goods and services that use creativity and intellectual capital as primary inputs.

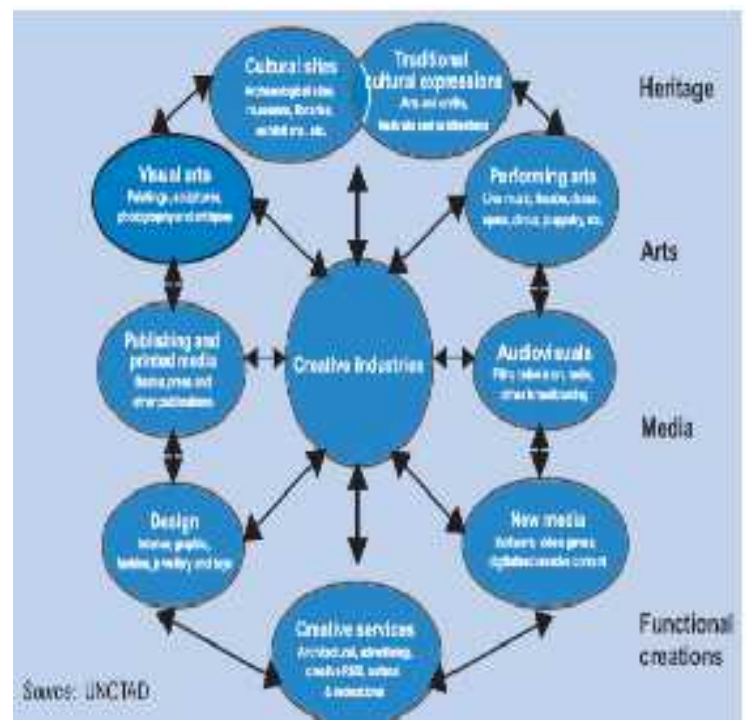

Fig. 1. Theoretical Framework

These industries incorporate a set of knowledge - based actions that create tangible goods and intangible intellectual or artistic services with creative content, economic value and market objectives. World Bank (2005) stated that Creative industries constitute a vast and heterogeneous field dealing with the interplay of various creative activities ranging from traditional arts and crafts, publishing, music, and visual and performing arts to more technology - intensive and service - oriented groups of activities such as film, television and radio broadcasting, new media and design. The creative sector has a flexible and modular market structure that ranges from independent artists and small business enterprises at one extreme to some of the world's largest conglomerates at the other (Figure 1)

This paper presents an analysis of Puncak 2 using this UNCTAD model of the creative economy, including the following aspects:

a. Heritage. Cultural heritage is identified as the origin of all forms of arts and the soul of cultural and creative industries, divided into two subgroups:

- Traditional cultural expressions - arts and crafts, festivals and celebrations.

- Cultural sites - archaeological sites, monuments, museums, libraries, exhibitions and so on.

b. Arts. This area includes creative industries based purely on art and culture. Artwork is inspired by heritage, identity values and symbolic meaning, divided into two large subgroups:

- Visual arts - painting, sculpture, photography and antiques. 
- Performing arts - live music, theatre, dance, opera, circus and puppetry.

c. Media. This area covers two subgroups of media that produce creative content with the purpose of communicating with large audiences ("new media" is classified separately):

- Publishing and printed media - books, the press and other publications.

- Audiovisuals - film, television, radio and other broadcasting.

d. Functional creations. This area comprises more demand driven and service oriented industries creating goods and services with functional purposes, divided into the following subgroups:

- Design - interior, graphic, fashion, jewelry and toys.

- New media - software, video games and digitized creative content.

- Creative services - architecture, advertising, cultural and recreational activities, creative research and development (R\&D), digital and other related creative services. (UNCTAD, 2006).

\section{METHODS}

The methods of this paper follows Goede and Louisa (2012) to analyze the possibilities offered by the area of Puncak 2 in the context of becoming a creative zone, the following steps were taken. A literature review was conducted on the subject of the creative tourism destination zone. The area was intensively visited and observed. Interviews were held with key stakeholders.

There is a close relationship between the concepts of the creative economy and the creative tourism destination zone. While the former can be seen as an interaction between the creative assets of a region or country in generating economic activity, the latter, as defined by the United Nation Creativity Report 2008, is specifically related to an urban complex where cultural activities of various sorts are seen as an integral component of the city's economic and social functioning (UNCTAD, 2006).

The next step is to analyze the area of Puncak 2, applying the theoretical framework. In this case the framework is based on the United Nations Report published in 2008: The Creative Report 2008. That document is an extensive report that was the outcome of collaboration between five different United Nations organizations: UNCTAD, UNDP Special Unit for South-South Cooperation, UNESCO, WIPO and ITC. The report was the consequence of the increasing awareness on the part of these organizations of the potential of the creative economy to generate new jobs and income while promoting cultural diversification and human development.

The outline of this paper is as follows. After developing the theoretical framework, it is applied to the case of Puncak 2 with a focus on:

- A description of the area and identification of the creative industries in the area. The matrix developed by UNCTAD is used.
- The factors identified to the characteristics of the creative zone of Puncak 2.

The preconditions for development, have been defined such as infrastructure and strong local culture identity.

\section{RESULT}

The development of Puncak 2 is considered slow. Figure 1 shows the map of Puncak 2 starting from Sentul Circuit to Puncak Pass and Cipanas. West Java Governor Ahmad Heryawan admitted to preparing a proposal to the central government to speed up construction of alternative roads Puncak 2 Sentul towards Cipanas. Although the process is expected to slow, but Aher insists he will continue to prioritize the development of alternative pathways Puncak 2, considering the demand is very urgent. (Syafrudin, 2016).

Table 1 describes the creative industries that can be proposed in the Puncak 2creative destination zone.Cultural heritage along Puncak 2 is not yet fully developed. The origin of all forms of arts and the soul of cultural and creative industries already well established in Puncak 1. Therefore Integrated Agro Multi Tourism in Puncak 2 need to be further developed to attract more tourist visit Puncak 2.

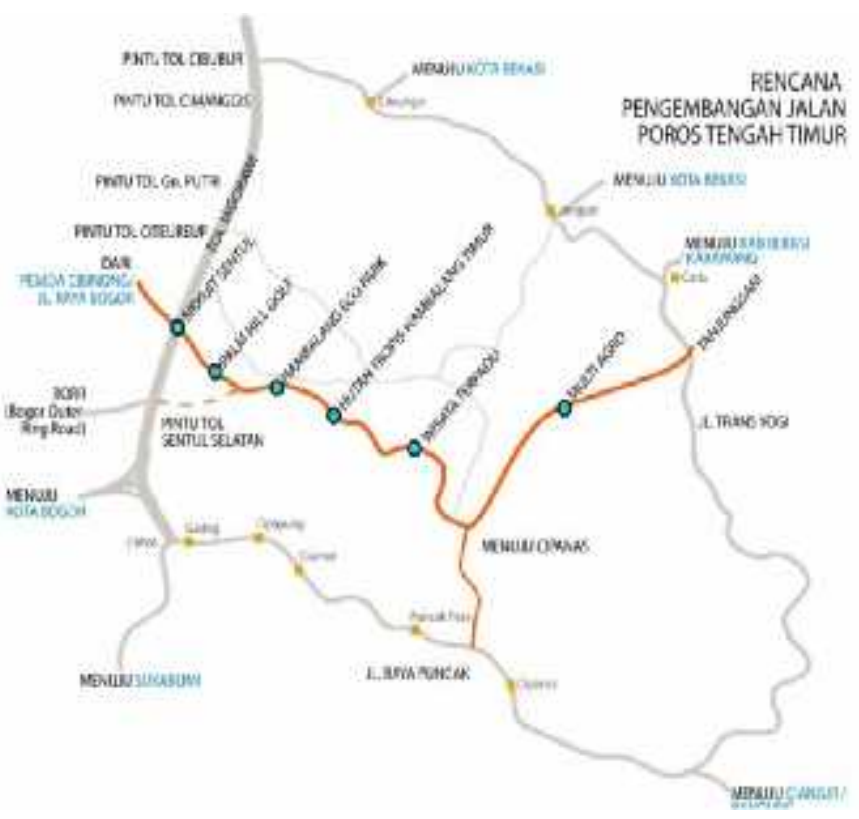

Fig. 2. Puncak 2 Line

Obstacle faced by industries in Puncak 2 Line is the slow process of infrastructure building, so government try to push this a priority. Aher revealed, request that the alternative road construction was one of them received the provincial government of West Java Police. Almost every week there is congestion outstanding in Puncak 1 line. Therefore it becomes urgent non-toll roads Puncak 2 from Sentul to Cipanas.

Cultural sites such as archaeological sites, monuments, museums, libraries, exhibitions are proposed to be developed in the area of Hambalang Tropical Forest. An alternative 
path Puncak 2 needed to complete the construction of toll roads Bogor-Ciawi-Sukabumi or Bocimi to reach Hambalang Tropical Forest. The motorway was not passing Cianjur so, the Puncak 2 was a viable alternative to the access of Cianjur, Bogor. At this time, the Department of Highways has been asked to study alternative road works Puncak 2 was to send the proposed acceleration of road that the central government.

Sentul Circuit area can be developed to provide creative industries based on sport, art and culture. Artwork is inspired by heritage, identity Sundanese values and symbolic meaning, such as painting, sculpture, photography and antiques.

Sentul International Convention Center has been developed as creative tourism destination zone to invite creative tourists to visit Puncak 2 zone for performing arts, live music, theatre, dance, opera, circus and puppetry.

Sentul Highland is a potential area that produce creative content with the purpose of communicating with large audiences such as publishing and printed media - books, the press and other publications.

\section{TABLE I. CREATIVE TOURISM INDUSTRIES IN PUNCAK 2}

\begin{tabular}{ll}
\multicolumn{1}{c}{ Aspects } & \multicolumn{1}{c}{ Destination } \\
\hline $\begin{array}{l}\text { Traditional cultural } \\
\text { expressions }\end{array}$ & Integrated Agro Multi Tourism \\
Cultural sites & Hambalang Tropical Forest \\
Visual arts & Sentul Circuit \\
Performing arts & Sentul International Convention Center \\
Publishing and printed & Sentul Highland \\
media & \\
Audiovisuals & Hambalang Ecopark \\
Design & Palmhill Golf \\
New media & Hambalang \\
Creative services & All sites \\
\hline
\end{tabular}

Hambalang Ecopark has been used for outdoor studio for film, television, and other broadcasting. This creative zone supports Puncak 2 line road construction connecting Sentul Bogor Regency with Cipanas Cianjur Regency. The process of road construction Puncak 2 line not only unravel congestion but also improve the community economy Bogor and Cianjur. Of course this could be an opportunity to invest in the district. So it must be encouraged.

To note, the development of Puncak 2 line is divided into three phases. The first, built along $28 \mathrm{~km}$ and a width of 30 meters starting from Babakanmadang-Sukamakmur-Jonggol. The second phase, Sukamakmur-Cariu (Road Transyogi) with a length of $15 \mathrm{~km}$ and the last that is to build up Cipanas Sukamakmur lanes along $10 \mathrm{~km}$.

Puncak 2 road construction as an alternative route to get to the tourist area of Bogor Regency urgent to be solved. The link between the Bogor regency via Babakanmadang, Sukamakmur, Tanjungsari up to Kota Bunga, Cipanas Cianjur it becomes important considering the current density at the Puncak increasingly complex.

Community feel, the more days the path to Puncak ranging from Ciawi up to Gunung Mas tea plantation began uncontrollably. On certain days such as Saturday-Sunday, confirmed experiencing severe congestion. While the imposition of open and closed paths by Bogor Police considered less helpful.

Palmhill Golf offers service - oriented industries creating goods and services with functional purposes such as interior design, graphic, fashion, jewelry and toys.

Hambalang area is potential site to offer New media such as software, video games and digitized creative content. The majority of land access road has been provided despite several sections of unfinished release. Puncak 2 land alternative road was partly financed by the provincial government, while the physical construction of the course by the central government.

All sites along Puncak 2 line are proposed to provide creative services such as architecture, advertising, cultural and recreational activities, creative research and development (R\&D), digital and other related creative services.

Further analysis found that Cikarang, the nearest growing city from Puncak 2 and east side of Jakarta, is the center of attention of industrialists Indonesia and even foreigners. As the largest CBD in Indonesia, Cikarang is the mecca for CEOs of industrial companies to plug factory / her business there. A variety of residential projects in Cikarang and surrounding that is currently rife offered by the developers always Sold Out. So Cikarang can support Puncak 2 to be further developed as creative tourism destination zone to increase economic competitiveness of Bogor District.

Imagine 10,000 Expatriate working in about 2,000 factories / industries in Cikarang and around the CBD will color it with modern and metropolitan lifestyle. At the same time tens of thousands of local executive will also meet the CBD in every residential and public areas. Do not forget the hundreds of thousands of workers who work to make Cikarang and surrounding areas come alive both day and night.

Although some mega projects such as Plaza Indonesia Jababeka and township Orange Country will absorb the social life and recreation of the inhabitants, keep all of this feels very lacking. The residents of Cikarang, whether expat, local executive and workers need a fresh nature, cool that can not be given by the AC at malls or workplace. Lucky together with the rapid development in Cikarang, the government is preparing a $30 \mathrm{~m}$ wide road access connecting Cikarang (Deltamas) with Cipanas. The project is called the Puncak Line 2 or often called the Central Axis Line East.

In essence, once the overall project is completed, for those of you who live in Cikarang only takes approximately 30 minutes to arrive at the hotel or the tourist attractions of your choice in Cipanas. With impartial comparison, you need time 2 times as much to reach Kelapa Gading / Jakarta State / Blok M.

Puncak 2 line not only shorten the time to get to Cipanas Jakarta citizens, but also open up access that has not ogled. Massive construction in Cikarang will require access to the various parts that will support the success of development itself. Puncak area-Cipanas is the only cool area within a radius of less than $50 \mathrm{~km}$ from Cikarang.

Puncak 2 line will open the lines of the 'new' which enables Top Executive at a company in Cikarang has a home stay in 
Puncak-Cipanas and offices every day in Cikarang, because the travel time both locations just 30-45 minutes! A healthy and productive lifestyle.

On the one hand, Cikarang with strong industry links and well-equipped, on the other hand-Cipanas Puncak cool and filled with nature-based tourist attractions. In the past need helicopters to get both as part of life every day, but this time Line Puncak 2 is a cheap solution, and like a godsend as a door that had been closed are now open.

The nature and people along Puncak 2 are amazing. A paddy field on the right and left of the winding road leading to the foot of the mountain. Malingping, a village in the district not far from Jonggol Cariu. If you know the fruit garden Mekarsari, then Cariu is still about 1 hour drive towards cianjur. Mekarsari, Jonggol, until Cariu as an economic buffer and satellite Jakarta is very large. Not inferior to Depok, Cisarua, Sentul, Bogor or Tangerang.

What is interesting is the discussion Cariu be saving a lot of economic potential movers. Call it the agriculture, livestock and tourism. Everything can be an investment opportunity for the citizens of Jakarta, many money. For example: investment teak garden, catfish cattle, and goats. Return can be above $50 \%$ per year. Puncak 2 can be economically competitive compare to Puncak 1 which has been long time fully developed.

But the economy can grow with the terms: infrastructure better road access (if necessary, there are alternatives other than cibubur, residents still hope Access Puncak 2), and human resources that has the spirit of developing the area, trust, and skillfully manage. Culturally, the Cariu friendly and courteous. The proof, there were mutual help mothers make dodol for celebration, and as guests of course our greetings and exchanged greetings. As a result, guests were given a bundle dodol just created.

Nothing exciting here. Although not all residents like this, but education is still unequal makes some residents do not understand the outhouse healthy. Do not be surprised if you are asked where the toilet, you can be invited to an existing pond fish

\section{CONCLUSION}

To summarize, the Puncak 2 zone already has the most important characteristics identified in the classification of the UNDP to be categorized as a creative economiy to suppport tourism destination zone.

Finally, to be successful it is important to have a large, networked community. There must be networking between firms, within firms, within similar sectors and across sectors, as well between the sectors and the university, government agencies, NGOs and commercial companies.

After analyzing the creative zone using created theoretical framework, the conclusion is that the some zone is populated by creative industries, especially the part of Sentul. The zone has the characteristics of creative industry due to the fact that it is used primarily by the tourist industry as a showcase of the heritage.

The best solution is to open Puncak 2 Line. Therefore, if there's Puncak 2 Line, we hope Cianjur tourism climate, the future can be better and tourists can more easily get into the area Cipanas.

The development budget Puncak 2 Road has been submitted to the central government, so that the main obligation of development in the central government of Indonesia.

Puncak 2 Road is not included in the local budget, because it is done by the central government, including the development of road links between Sentul-Cianjur, which is included in the plan of the central government in this case the Ministry of Public Works and Housing. Meanwhile, the land acquisition for the expansion of Jalan Puncak 2 is likely to be handed over to the local government, regional government and local government Bogor Cianjur.

Puncak 2 Line could be one solution to overcome congestion in Puncak-Cipanas tourist area. Furthermore, it is expected to boost the economy of the community by creating creative tourism destination zone.

\section{REFERENCES}

Goede Miguel, Gunnar Louisa, (2012) "A case study of the creative zone Scharloo and Pietermaai in Curaçao", International Journal of Social Economics, Vol. 39 Iss: 11, pp. $844-858$

Howkins, J. (2001). Creative Economy. London: Allen Lane.

Jelincic, D. A., \& Zuvela, A. (2012). Facing the challenge?Creative tourism in Croatia. Journal of Tourism Consumption and Practice, 4(2), 78-90.

Porter, M. (1999). The Competitive Advantage of Nations. New York, NY: The Free Press.

Richards, G. and Raymond, C. (2000) Creative tourism. ATLAS News, 23: 16-20.

Syafrudin, Reno (2016). Jalur Puncak II http://www. jalurpuncakdua.com/2016/01/jalur-puncak-ii.html, retreived on 20 October 2016.

Gubernur Akan Percepat Pembangunan Jalur Puncak II http://www. Jalurpuncakdua. com/2016/10/gubernur-akan-percepat-pembangunan.html, retreived on October 20, 2016.

UNCTAD (2006). Creative Economy and Industries Programme, United Nations Conference on Trade and Development, Geneva.

UNESCO (2008). The Creative Economy Report 2008: The Challenge in Assessing the Creative Economy - Towards Informed Policy Making, Paris: UNESCO

World Bank (2005). "Dynamic cities and creative clusters", World Bank Policy Research Working Paper 3509, February. 